\title{
Kaftar Kouh of Ferdous, New Evidence of Paleolithic Population in Southern Khorasan, Iran
}

\author{
Ali Sadraei', Mehdi Fallah Mehneh ${ }^{2}$, Mohammad Sheikh ${ }^{3}$, Bahram Anani ${ }^{4}$, \\ Zahra Hedayati Minaei ${ }^{5}$ \\ ${ }^{1}$ Tarbiat Modarres University, Tehran, Iran \\ ${ }^{2}$ Torbat Heydarieh University, Torbat Heydarieh, Iran \\ ${ }^{3}$ Archaeology Department of Torbat Heydarieh University, Torbat Heydarieh, Iran \\ ${ }^{4}$ Art University, Isfahan, Iran \\ ${ }^{5}$ University of Neyshabur, Neyshabur, Iran \\ Email: sadrayi.ali@gmail.com
}

How to cite this paper: Sadraei, A., Mehneh, M. F., Sheikh, M., Anani, B., \& Minaei, Z. H. (2019). Kaftar Kouh of Ferdous, New Evidence of Paleolithic Population in Southern Khorasan, Iran. Advances in Anthropology, 9, 111-123.

https://doi.org/10.4236/aa.2019.92009

Received: March 7, 2019

Accepted: May 24, 2019

Published: May 27, 2019

Copyright $\odot 2019$ by author(s) and Scientific Research Publishing Inc. This work is licensed under the Creative Commons Attribution International License (CC BY 4.0).

http://creativecommons.org/licenses/by/4.0/

\begin{abstract}
The eastern part of Iran, especially Khorasan, has remained in a completely unclear and vague state in spite of the fact that Paleolithic studies have been the pioneer of archeological research. In the meanwhile, the condition of the lower Paleolithic period is wretchedly worse, so that the only evidence of this period is that obtained of two widely-cited sites, namely Kashfroud and Daroungar River (Artian); while in other parts of Khorasan no evidence indicating the presence of Pleistocene hominin populations has been published to this date, which is largely questionable and requires a revise on the archaeology of the Paleolithic era in this part of Iran. Kaftar Kkouh site of Ferdous is among the latest Paleolithic evidence found in southern Khorasan, located in the southeastern part of Ferdous, $2 \mathrm{~km}$ from the city of Ferdous, on the hills overlooking Ferdous Plain. From among the Lithic artifact obtained from these two sites, Bifacial chopper-core, Unifacial chopper-core, radial cores, crude flakes, and Levallois that according to the knapping type and technique used are likely to be attributed to the late lower Paleolithic era and the early Middle Paleolithic period. In the present paper, the authors seek to provide a relative chronology for these devices in addition to their morphology, and compare them with the surrounding Paleolithic sites such as Kashfroud, Daroungar, etc.
\end{abstract}

\section{Keywords}

Khorasan, Ferdous, Paleolithic, Kaftar Kouh 


\section{Introduction}

Due to its particular location, the Iranian plateau has served as a connecting bridge between several continents which has played an important role in movements and displacement of Pleistocene populations in the central parts of Asia (Bar-Yosef \& Cohen, 2001; Otte, 2015). This is despite the fact that unfortunately the Paleolithic archaeological research in Iran, has not been considered as much as it really deserves, and the number of explored and cited sites, is too low to be able to provide a clear and obvious view of the hunter-gather populations who had been active in this part of the plateau. Meanwhile, the eastern part of Iran is even in a much worse state, and from the point of view archaeological data, this area of Iran provides one of the poorest archaeological data of the $\mathrm{Pa}$ leolithic period, most of which date back to the past decades (for example, see: Coon, 1951; McBurney, 1964; Ariai \& Thibault, 1975). Although over the last decade, these studies have been increased in number, two major problems regarding these kinds of studies hinder the development of such research. The first problem is the lack of precise and coherent planning to follow specialized research in this area, so that such studies, except for a handful of them, are mainly considered as part of archaeological research programs, rather than an independent program. The second problem is associated with the studies and research that are started from the stage of sampling on the surface of the site and continued until the stage of publication of information and even storage of the data, and unfortunately, the outcome of these studies cannot solve the main issues and questions posed about the knapping industry and the livelihood of Paleolithic populations in this part of Iran as much as it is really needed. This is despite the fact that in the vicinity of Khorasan region and in the central part of the plateau of Iran, extensive studies have been carried out over the past years, which have continued so far and altered the status of awareness and knowledge about the Paleolithic populations in this area (see Vahdati Nasab et al., 2010; Vahdati Nasab et al., 2013; Vahdati Nasab \& Hashemi, 2016; Vahdati Nasab \& Hashemi, 2018; Vahdati Nasab \& Feyz, 2004; Vahdati Nasab et al., 2007).

In the meantime, perhaps, the first study in Khorasan carried out after Ariaei, Tibo and McBurray's studies could be the revisit of the Paleolithic sites of Kashfroud in Mashhad plain, the results of which supported Ariaei and Tibo's studies to some extent (Jami Al-Ahmadi, 2008); also, another research conducted in this area is the identification survey of Chehel Dokhtaran site of Sarbisheh in southern Khorasan, which is attributed to the Middle Paleolithic period according to the knapping technique and the use of Levallois technique (Barfi \& Soroush, 2014). Moreover, another site in Bayaz Plain near the modern city of Khezri has been identified which was initially attributed to the Middle Paleolithic period and Epi Paleolithic era (Barfi et al., 2014). However, in the reviews conducted, part of the obtained tools has been attributed to the Upper Paleolithic period (Biglari, 2015: p. 20). In addition, from among the six locations near the modern city of Khosf, called Qala Khannad 1 and 2, Kamarbik, Lakh Atash, Barandaz, 
and Sarab-e Hamand sites, a number of Lithic artifacts have been identified that according to its researchers they can be attributed to the Middle Paleolithic era (Nikzad et al., 2015), although the published information is more in the form of a short report extracted from an extensive field report, and no information can be gained of the quality and situation of knapping industries of the mentioned sites (Nikzad et al, 2015: p. 3). The southern site of Damghani, on the suburbs of the present-day city of Sabzevar, is another settlement providing evidence of the Paleolithic period and it is attributed to the Middle Paleolithic era according to the morphology of the obtained stone tools (Sadraei et al, 2017). Among the other Paleolithic evidence identified are the suspicious findings discovered in the northern parts of Khorasan and from the dried riverbed of Daroungar River (Artin), located $5 \mathrm{~km}$ north of Dargaz. According to the researchers, these areas are attributable to the Lower Paleolithic period (Sadraei et al., 2018). However, with regard to the identification location and context of these Lithic artifacts, which have a distressed and non-stitue condition, one should be very cautious in assigning them to any period of time. The most recent evidence related to the Paleolithic period is the evidence found in the Sarayan region. Kalat-e Shour settlement, located in the eastern part of the modern city of Sarayan, represents an open-air site that has been formed on the outcrops of stone raw chert material that along with the composition of the samples Lithic artifacts has greatly increased the likelihood that this place has been used as a workshop area (Sadraei \& Anani, 2018). Considering the abundance of Levallois technique and the presence of official tools including different types of scrapers, especially denticulates that have been introduced as the representative tools of this period (see Shea, 2013: pp. 100-102), the above-mentioned site has been attributed to the Middle Paleolithic period (Sadraei \& Anani, 2018).

In the meantime, the open-air site of Kaftar Kouh, located at the eastern highlands of today's Ferdous city, is considered among the latest findings of the Paleolithic period of Khorasan region. The mentioned site was identified on the hills overlooking the city of Ferdous during a project in which the historical monuments of the city were being registered in the list of national monuments (Figure 1). In this research, the authors have attempted to study the morphology of the aforementioned Lithic artifact and carry out statistical and comparative studies to examine the different dimensions of its knapping industry. The aforesaid site, which is in fact situated in two locations, approximately 500 meters apart from each other, consists of a set of stone tools with Lower Paleolithic period characteristics, including Bifacial chopper, Unifacial chopper, radial cores, crude flakes, heavy scrapers and, that a number of Middle Paleolithic stone tools, such as radial cores, Levallois flakes and Levallois blades are also recognizable alongside them, reinforcing the probability that this site may have had two periods. Though it should be noted that the amount of data available is too low to be certain about their assignment to these two periods, and perhaps in the most logical state, they can be attributed to the late Lower Paleolithic period. 


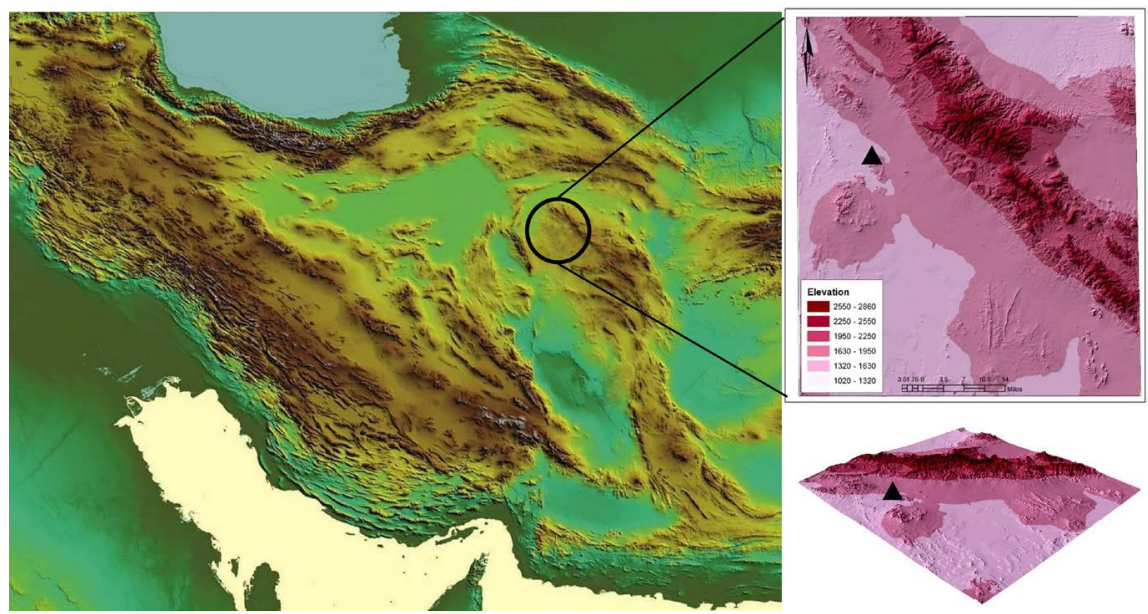

Figure 1. Location of Kaftar Kouh Site in Ferdous Plain.

\section{Geography and Geology of the Region}

The modern city of Ferdous is located between two low-altitude mountain ranges, i.e. Kalat, Siah and Mount Zool in the east and Mount Tabas in the west, the highest of which is the Mount Siah with a height of 2813 meters. Due to being located near the central desert of Iran, this city has an arid and desert climate and is divided into two parts: mountain (north) and plain (south).

The highest highlands of Southern Khorasan are located in the north-east of Ferdous. These heights extend from north-west to south-east, and from there to southern Bajestan, west of Ghayen and Gonabad. The highest peak of this mountain range is Mount Siah (Siahh Kook) with a height of 2813 meters. Another mountain range which is almost parallel to the former chain is situated in the southwestern part of Ferdous city. This low-altitude mountain range in Ferdous limits has taken the form of some hills, and the farther it moves to the southeast direction, the higher its height becomes. And eventually, it joins the mountains of Birjand. In Ferdous limits, these mountain ranges appear with different names, with its two peaks being known as "Kouh-e Qala" and "Kouh-e Hassan Abad" due to having two historical fortresses related to the Ismaili period.

Ferdous region is one of the major units which is located in the center of Iran in the form of a triangle and is one of the largest and most complex units of geology. The geological formations in this region are located along the North-West-South-East direction. The traces of different orogenic and tectonic movements are visible in most parts of the region. Angular deformation and erosion, lack of sedimentation, faulting, volcanic activities, and folding are manifestations of orogenic movements and tectonic activities which are seen in different parts of the region. The age range of the existing deposits in the region extends from Precambrian to the present time. A large part of the metamorphic stone is seen in the north and north-east of the region. Precambrian sedimentary and Paleozoic rocks mainly appear in the west and southwest of the region, and plutonic and volcanic rocks are more commonly found in eastern parts of the 
region (ibid: 101).

The dominant stones can be found in the form of andesite and basalt rocks on different parts of the plain and the foothills. Which can be a good source of Lithic artifact sandals in the absence of Chert outcrops. What is also seen in the composition of the stone tools of the study set and will be referred to below. On the other hand, the lack of severe sedimentation in the region makes it possible to obtain more findings from the Paleolithic Period (in the presence of the data of this period) in the hilltop sections.

\section{Kaftar Kouh Site, Sampling Method and Findings}

Kaftar Kouh site of Ferdous is located $2 \mathrm{~km}$ from the eastern highlands of the modern city of Ferdous and on the hills overlooking the river Chehel. During the project, the authors survey the river boundary sections and in the part overlooking the plain of Ferdows. During the project, the authors survey the river boundary sections and encountered suspicious evidence in the plain overlooking the Ferdows plain. Initially, it was decided to systematically sample the site, therefore, at the beginning, the project was performed in a completely intensive manner, determining that the dispersion rate of the stone tools was low and they could only be identified in two locations with an approximate distance of $500 \mathrm{~m}$ from each other (Figure 2).

Therefore, due to the limitations existing during the systematic sampling process, sampling was done selectively, and attempts were made to sample the data as far as possible, which ultimately resulted in two general locations named K.A and K.B, from which the samples were taken. The location K.A with approximate dimensions of $230 \times 60 \mathrm{~m}$ with a southeast-northwest direction was the area from which the highest proportion of core- chopper were obtained, and a total of 19 lithic artifacts were sampled; and location K.B, in which the dimensions and extent of the distribution of the findings were 150 meters to the

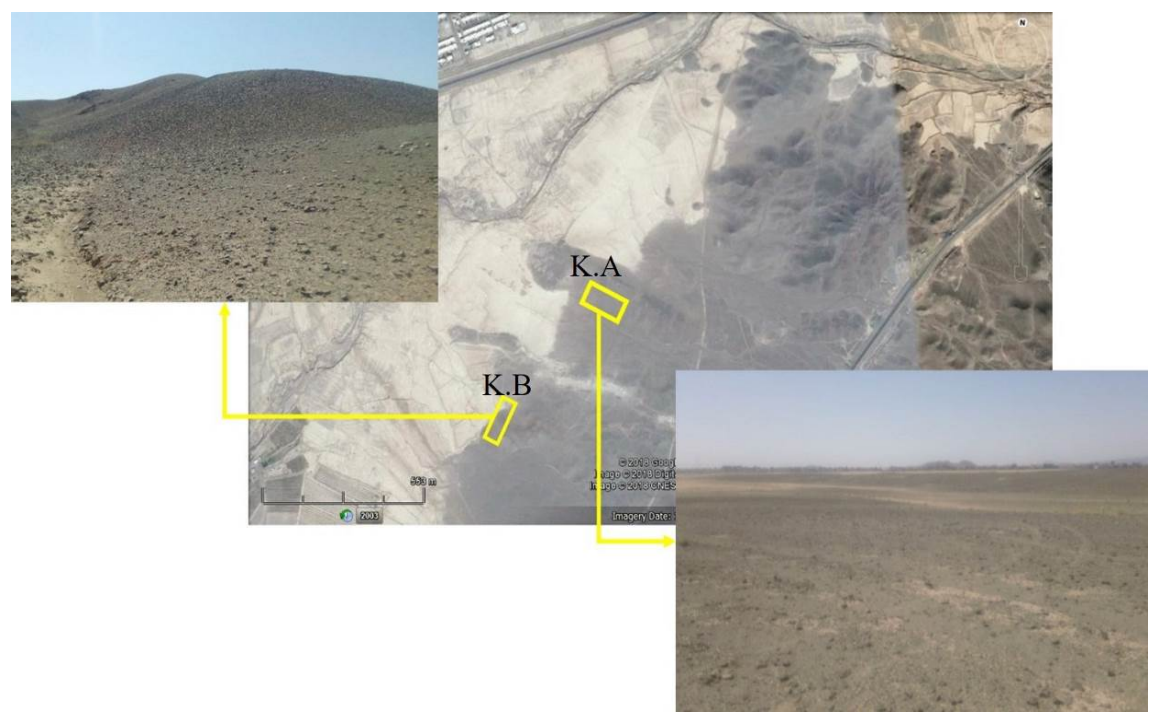

Figure 2. General view of Kaftar Kouh, Ferdous. 
southwest-northeastern direction and 30 meters to the eastern-western direction, and the samples discovered in this section dominated by debitages, in particular quartz, that totally 37 lithic artifacts were identified. At the end of the sampling process, four samples of cores and their fragments, 38 pieces of debitages, 8 pieces of tools, and finally 6 pieces of debris were collected from the two positions. The quantity and distribution of each of them varied in two situations (Table 1).

In spite of the fact that the lithic artifacts obtained from Kaftar Kouh of Ferdous site are limited, it should be noted that the mentioned samples are considered among the little Lower Paleolithic evidence discovered in Khorasan. Whilst, related evidence has been only obtained from two other areas in Khorasan (Kashf Roud and Daroungar River?) and the evidence of these collections is also very limited, in such a way that the largest collection of this region hardly provides more than 40 stone artifacts (see Biglari, 2015: p. 21). Therefore, in the final analysis, in addition to the techno-typological study of the artifacts, the results are compared with adjoining sites such as Kashf Roud and Daroungar River (Artian).

\section{Raw Stone Material Used}

Stone, water and food resources have been always considered as the main factors in the selection and use of a site (Adib Zade \& Vahdati Nasab, 2016: p 109). Among these, stone as a tool for obtaining food is of double importance and the study of raw stone dispersion is an appropriate solution to solve the problems associated with living places of prehistoric humans and the surrounding areas, their exchanges and social interactions (Inzian et al., 2010: p. 39), and the selection of the place of residence and the migration of primary instrumentalists is to some extent affected by how they could find raw stones needed to make the required lithic artifacts (ibid. 29).

During the surface survey of the site, scattered fragments of basalt as well as quartz stones can abundantly be observed. This important issue according to the high proportion of raw material used in Kaftar Kouh collection can reinforce the likelihood that the required stones had been suppled locally, so that among the raw material groups used, quartz stone constitute more than half of the collection (55.3\%) (Figure 1). It is noteworthy that quartz stones are one of the main groups of stones used by primary instrumentalists (Ambrose, 2001: p. 1749). And in the sites attributed to the ancient Paleolithic period in Khorasan

Table 1. Frequency of stone artifacts in two sampling locations on the surface of Kaftar Kouh Site.

\begin{tabular}{ccc}
\hline Location & Frequency & Percentage \\
\hline Location K.A & 19 & 33.9 \\
Location K.B & 37 & 66.1 \\
Total sum & 56 & 100 \\
\hline
\end{tabular}


(Jami Al-Ahmadi, 2008; Biglari, 2015: p. 21) and Central Asia, this group has been used more than others (Davis \& Ranov, 1999). Basalt stone was the most frequently used material to produce the lithic artifact (17.8\%), whose primary material was abundantly scattered over the area (Figure 3 ), followed by tuff stones (10.7\%), Chert stone (7.1\%), Calciodine (5.3) and finally flint (3.5\%). Unfortunately, among the above-mentioned groups, no outcrops of Chert and Flint were found on the surface or adjacent to the site, perhaps the most important source could be rubbles on the riverbed of the seasonal river, which is flowing in the north and northwest of the site.

An important point is the high frequency of basaltic stons and tuffs in location K.A, where the predominant stone artifacts are choppers, heavy scrapers and crude flakes, which have mostly used these two types of stones. While in location K.B no evidence indicating the use of these two stone has been identified, it should be noted that the stones used in location K.B are mostly quartz stons (Chart 1).

\section{Compositions of Cores and Debitages}

Generally, in the sampled collection, cores have the lowest frequency among the artifacts (8.9\%) (Chart 2) and they are divided into three categories, including Bifacial chopper-cores (3 pieces), Unifacial chopper-core (3 pieces), radial cores (1 piece), and core fragments (1 piece). Among them, chappre-cores are one of the most significant Paleolithic artifacts (Shea, 2013: p. 50) and they are only found in K.A position, made of basalt and tuff. The average length of stone tools in Kaftar Kouh collection is $70 \mathrm{~mm}$ and the average width is $50 \mathrm{~mm}$, while the average weight is $85 \mathrm{~g}$, with less than 5 percent of the patina being visible on them (Figure 4 and Figure 5). Approximately $30 \%$ of the cortex remains on the cores that along with the average negative removal (9 debitages) indicate the optimal use of the existing cores. This has been somewhat justifiable due to the low frequency of cores in the collection. According to the fractures and the traces of deep debitages on cores, the possibility of using direct impact hammer stone technique can be high.

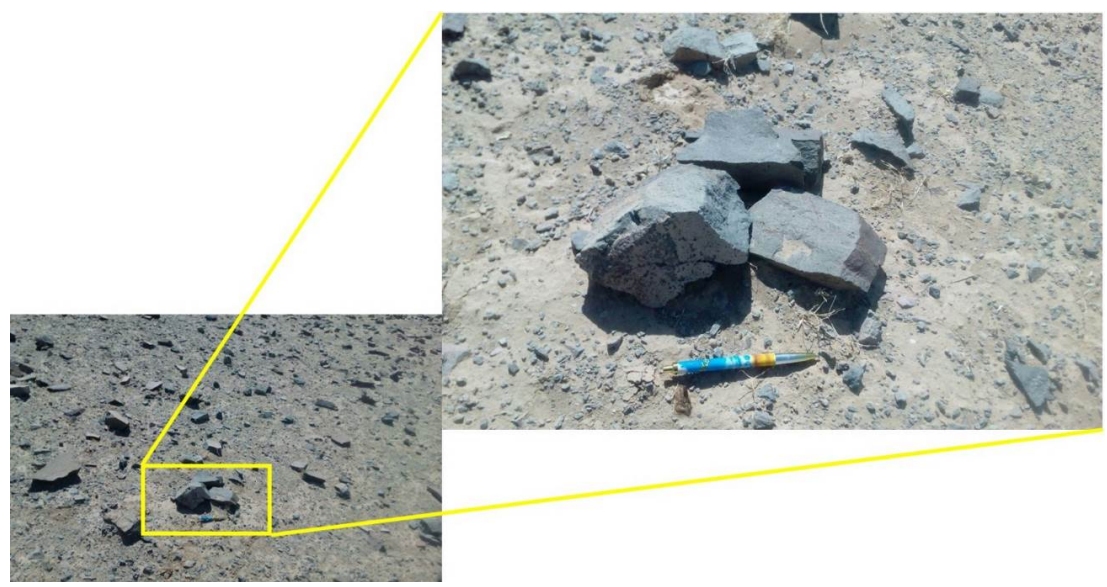

Figure 3. Basalt raw stone material existing on the surface of the site. 


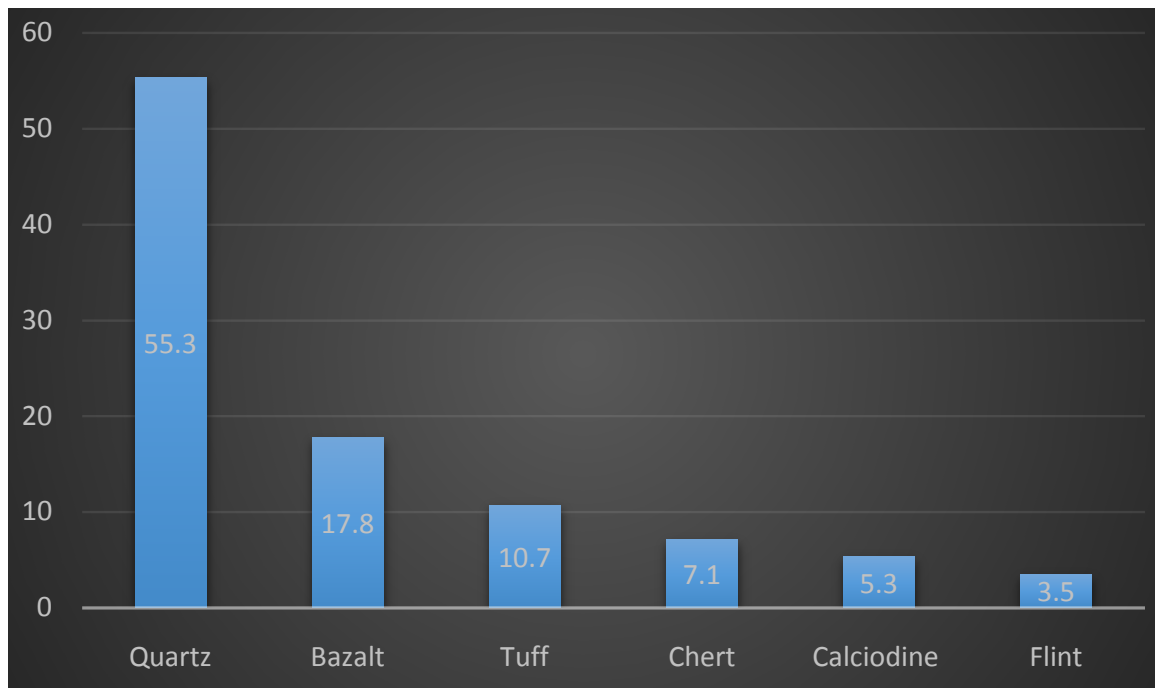

Chart 1. The raw material used in artifacts of Kaftar Kouh (\%).

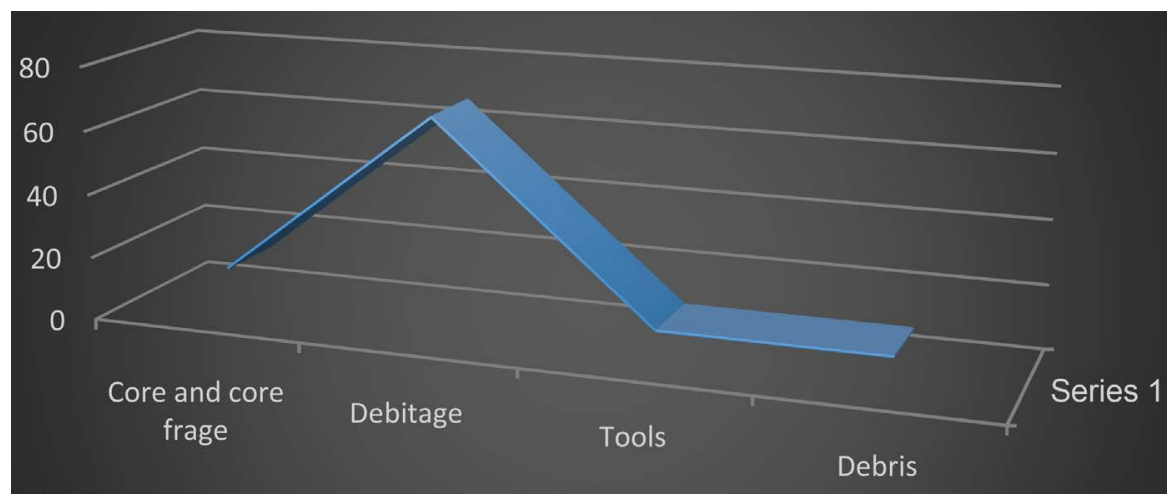

Chart 2. The general composition of the lithic artifacts obtained from Kaftar Kouh Site.

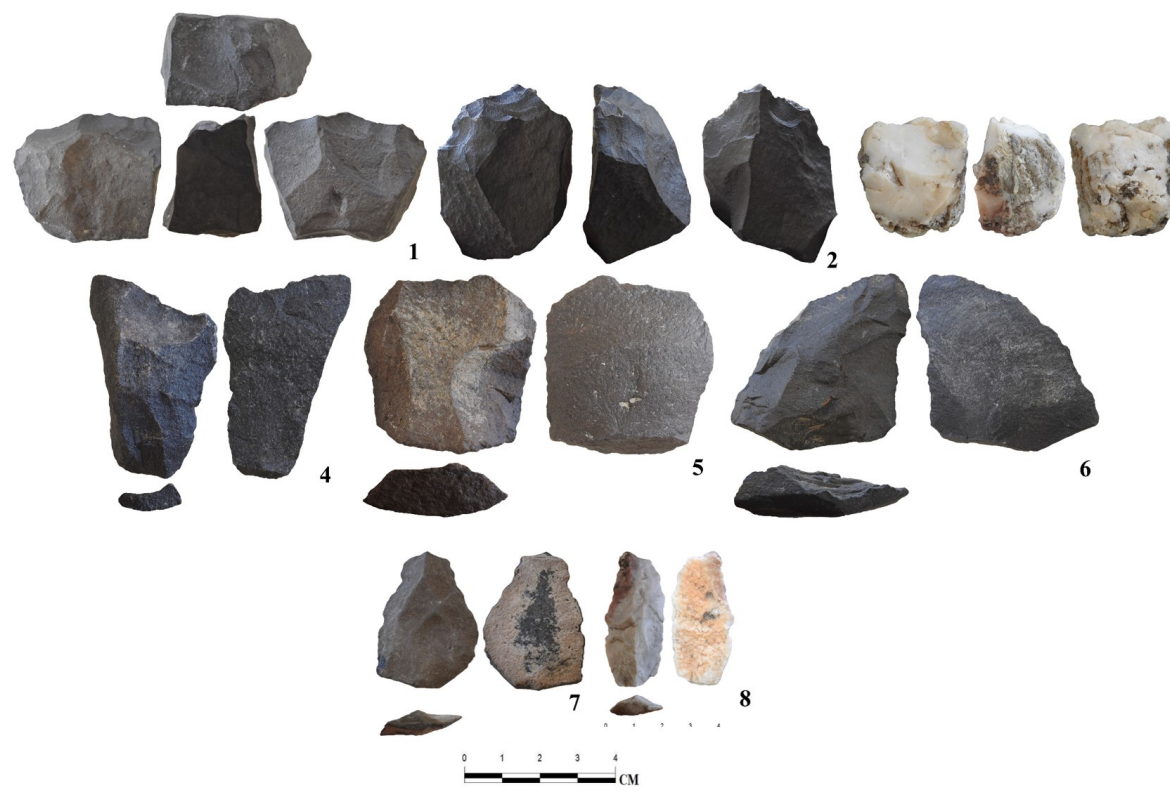

Figure 4. Selection of artifacts discovered in Kaftar Kouh Site. 1 - 3 Chopper-Core, 4 - 5 Crude flake, 6 - 7 Levollois flake, 8 Levollois Blade. 


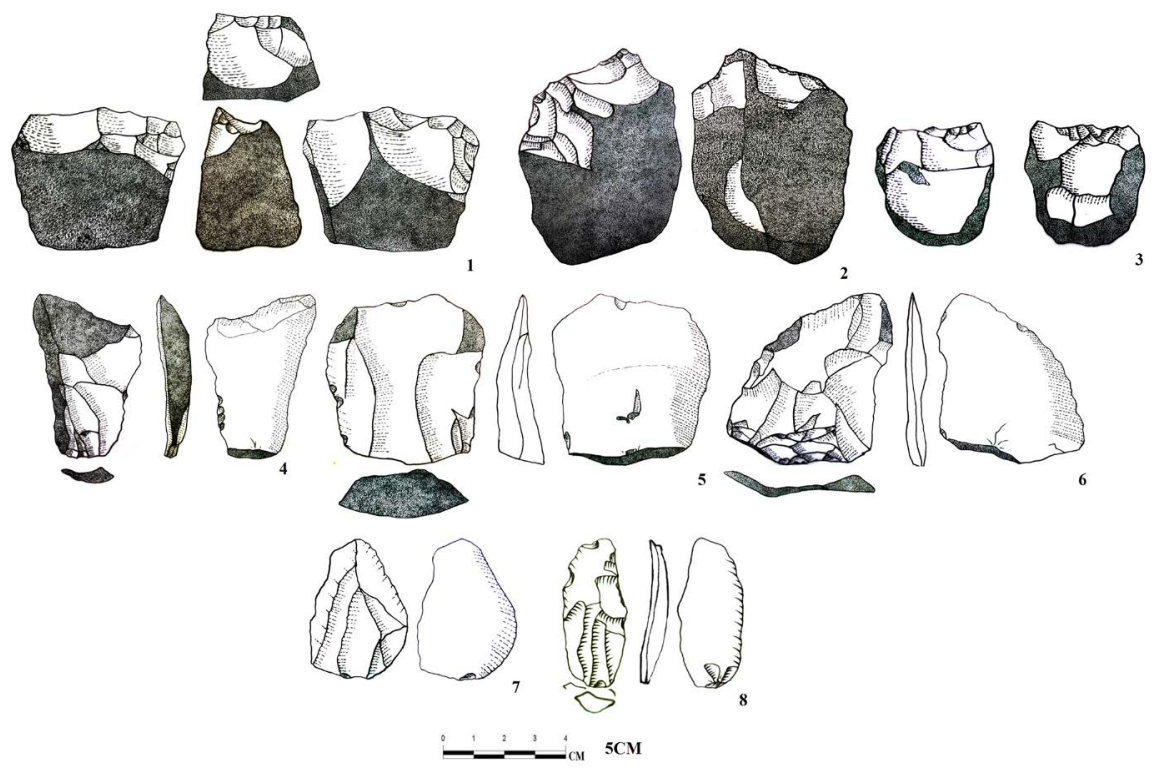

Figure 5. Selection of artifacts discovered in Kaftar Kouh site. 1 - 3 Chopper-Core, 4 - 5 Crude flake, 6 - 7 Levollois flake, 8 Levollois Blade (drawings by Ali Sadraei).

Among the lithic artifact collection of Kaftar Kouh, debitages have the highest frequency (Table 2) and they are divided into 38 pieces in the form of 7 groups. Broken flakes with 16 pieces have the highest frequency, among the fracture types, Siret group constitutes the most frequent fracture type (37.5\%). It should be noted that in this type of fracture, the flakes are split in the direction of its debitage axis (Inzian et al., 2010: p. 55). Afterwards, the distal end fractures (31.25\%), the fractures near the impact platform $(18.75 \%)$ and lateral edge fractures $(12.5 \%)$ were the major fractures, respectively, which were partly affected by the set of tools in the collection, because more than half of the collection is consisted of quartz. They are followed by cortical flakes and crude flakes which are consisted of 7 pieces, three pieces of blade, simple flakes ( 2 pieces), and finally Levallois blades? (1 piece) and Levallois flakes ( 2 pieces), in one case, the length reaches $8 \mathrm{~cm}$. They have been the other species identified in the group of debitages. Presence of Levallois blades and the Levallois flakes, one of which has a chapeu platform made of tuft and another that was severely eroded due to having been exposed to open air and a heavy patina has been formed on its ventral surface indicate the possible presence of this technique in the collection; although, given the small number of samples, it is impossible to discuss about the probability of their assignment to a particular period with more certainty (this technique has been mentioned as one of the major techniques in the knapping process during the Middle Paleolithic period) (Ambrose, 2001: p. 1750).

The amount of initial cortex is about $10 \%$ in the debitage group with an average length of $57 \mathrm{~mm}$, average width of $4.1 \mathrm{~mm}$, and an average weight of $34 \mathrm{~g} .6$ The relatively remarkable dimensions of the debitages, with their relatively high weight, according to the type and composition of the tools, indicates the focus of knapping process in the site, which has resulted in an increase in the debitage 
group in the entire collection, although this assumption could be expectable to some extent that at least some part of the knapping process has been performed on the surface of the site according to the presence of debitages along with cores and debris fragments.

\section{Tools and Retouched Pieces}

Another important group that has been evaluated in the Kaftar Kouh collection of lithic artifacts is the official tools and processed pieces. These groups are the largest group after the debitages ( 5 pieces) and are divided into 4 types of devices, whose distribution varies in two locations (Table 3). Among them, heavy scrapers ( 1 piece) were identified at location K.A, and transverse scrapers (1 piece) and side scrapers ( 1 piece) have been situated in location K.B along with the Retouched flakes. The existence of scraper group among the tool group, which has been mentioned as a characteristic of the Middle Paleolithic tools (Shea, 2013: p. 102) increases the probability of their assignment to the Middle period. On the other hand, as mentioned above, the presence of heavy scrapers along with Chopper-cores was one of the characteristics of the Lower Paleolithic period (Ibid: 50). The average weight of the tools group reaches $32 \mathrm{~g}$, with a mean length of $36 \mathrm{~mm}$ and a mean width of $39 \mathrm{~mm}$. Their amount of Retouched is often light and only the heavy scrapers have a modest degree of Retouched, which clearly demonstrates the lack of focus on purposeful knapping of lithic artifacts in the mentioned site. This issue along with the presence of chopper-cores

Table 2. Composition of the debitage group in Kaftar Kouh collection of Ferdous.

\begin{tabular}{ccc}
\hline Type & No. & $\%$ \\
\hline Broken Flake & 16 & 42.10 \\
Cortical flake & 7 & 18.2 \\
Crude flake & 7 & 18.2 \\
Blade & 3 & 7.9 \\
Simple flake & 2 & 5.26 \\
Levollois flake & 2 & 5.26 \\
Levollois Blade & 1 & 2.6 \\
Total & 38 & 100 \\
\hline
\end{tabular}

Table 3. Composition of tools and retouched pieces in the sampled locations.

\begin{tabular}{cc}
\hline Type & No. \\
\hline Side-scraper & 1 \\
Heavy scraper & 1 \\
Transverse scrapers & 1 \\
Retouched flakes & 2 \\
Total & 5 \\
\hline
\end{tabular}


with considerable sizes and the high percentage of debitages suggest that the main focus has been on the knapping of the lithic artifacts in an instant manner rather than in a purposeful way.

\section{Discussion and Conclusion}

As it has been mentioned, the eastern part of Iran has been largely forgotten in Paleolithic studies, and only when it is necessary to draw general maps and mention the regions with data related to this period, two points, i.e. Kashfroud in Mashhad plain and the Khounik Cave near the present-day city of Qayen, are mentioned merely as a case study; while the distance between them is about 500 kilometers, and the resulting data in one case (Kashfroud) have been collected from the riverbed and the riverside areas, which is very uncertain; and on the other hand, Khanik shelter (it should be mentioned that Khanik rocky shelter has been attributed to the Middle Paleolithic era (see: Coon, 1951)), has been explored a long time ago that has not been analyzed as it really deserves. Nevertheless, in spite of the existing shortcomings, the authors sought to compare the data obtained from Kaftar Kouh site with the sites which have the highest consistency according to the typology of the discovered artifacts.

Kaftar Kouh site in Ferdous may be comparable. It may be comparable with Pol-e Gazi, Qala Gak and Kashf Roud sites. From among the 5 features of tool-making identified in Kashaf Roud sites (Jami Al-Ahmadi, 2008: pp. 122-124), which include chopper-cores, chopping tools, polyhedron, heavy scrapers and convergent scrapers, four cases can be seen in the Kaftar Kouh collection. On the other hand, Kool Dara site in the south of Tajikistan, which has been identified among more than 100 meters of Los deposits, dates back to the Lower Paleolithic period and has a history of 800,000 years, also has had an axial knapping industry. This collection mostly includes wedge-shaped samples and flake cores with multiple impact platforms, and the samples are often made of quartz (Davis \& Ranov, 1999). Also, the collection obtained from the Daroungar River bed, which is mostly consisted of artifacts based on chopper-cores and chopper tools (Sadraei et al, 2018), can be compared with the collection obtained from Kaftar Kouh. In the meantime, the absence of a two-sided tool among the findings of Kaftar Kouh is one of the issues found in the samples of Kashf Roud and Daroungar sites; however, in the samples of Kaftar Kouh, no findings indicating the use of knapping technique in the form of double-side knapping have been identified.

With reference to the interpretations provided and given the fact that the data obtained are very limited, identification of the possible functions of the site is impossible; and on the other hand, the high dimensions of lithic artifacts and the low amount of Retouched, as well as the high percentage of debitages can support the immediate use of the stone tools, which in most cases has not been performed in a purposeful way. On the other hand, the presence of chopper-cores, crude flakes, and heavy scrapers, which are considered as the characteristics of 
Lower Paleolithic period, along with a sample of radial core, a Levallois flake and a Levallois blade, the probability of the general attribution of the total collection to the end of the Late Lower Paleolithic period and the early Middle Paleolithic period, although as mentioned previously, we cannot talk about the definitive attribution of this collection given the limited sample of the collection, and satisfactory results can only be obtained by conducting further complementary studies in the future.

\section{Conflicts of Interest}

The authors declare no conflicts of interest regarding the publication of this paper.

\section{References}

Adib Zade, M., \& Vahdati Nasab, H. (2016). Originating of Paleolithic Artefact Collection in Cham Souran Site in Ravand River Basin, Western Part of the Central Zagros. Journal of Quaternary of Iran, 2, 120-120.

Ambrose, S. H. (2001). Paleolithic Technology and Human Evolution. Science, 291, 1748-1753. https://doi.org/10.1126/science.1059487

Arie, A., \& Thibault. C. (1975). Nouvelles précisions a propos de l'outillage Paléolithique ancient sur galets du Khorassan (Iran). Paléorient, 3, 101-108. https://doi.org/10.3406/paleo.1975.4191

Barfi, C., Zaferanlu, R., \& Mohammadreza, S. (2014). An Paleolithic Open Air Site in City of Ghaenat, North of South Khorasan Province. In H. H. Zarjabad, \& S. M. Ghoreishi (Pre.), Iran National Archeological Forum. Chahar Derakht Publication Inc.

Barfi, S., \& Soroush, M. R. (2014). A Workshop on the Construction of Stone Artifacts from the Middle Paleolithic Period, Sarbisheh City, Southern Khorasan. In H. H. Zarjabad, \& S. M. Ghoreishi (Pre.), Proceedings of the National Archaeological Conference of Iran. Chahar Derakht Publication Inc.

Bar-Yosef, O., \& Belfer-Cohen, A. (2001). From Africa to Eurasia-Early Dispersals. Quaternary International, 75, 19-28. https://doi.org/10.1016/S1040-6182(00)00074-4

Biglari, F. (2015a). A Review on Paleolithic Archaeology in Khorasan Stressing on Kashafrud Sites. A Review on Archaeology of Khorasan: A Selection of Archaeological Findings and Historical-Cultural Antiquity of Khorasan. Prepared by Maysam Labbaf Khaniki, Tehran: Cultural Heritage and Tourism Organization.

Coon, C. S. (1951). Cave Explorations in Iran 1949, Museum Monographs. Philadelphia, PA: The University Museum, University of Pennsylvania.

Davis, R. S., \& Ranov, V. A. (1999). Recent Work on the Paleolithic of Central Asia. Evolutionary Anthropology: Issues, News, and Reviews, 8, 186-193. https://doi.org/10.1002/(SICI)1520-6505(1999)8:5<186::AID-EVAN6>3.0.CO;2-R

Inzian, M. L., Ballinger, M. R., Roush, H., \& Tiksieh, J. (2010). Technology and Terminology of Stoneware. Persian translation by Elham Qesidian, Tehran: Samira Publications.

Jami Al-Ahmadi, M. (2008). Review of Paleolithic Studies in Kashfrud River Basin and the Introduction of New Paleolithic Sites. Master's Thesis, Tehran: Department of Archaeology, Tehran University.

McBurney, C. B. M. (1964). Preliminary Report on Stone Age Reconnaissance in North-Eastern Iran. Proceeding of the Prehistoric Society, 30, 382-399. 
https://doi.org/10.1017/S0079497X00015176

Nikzad, M., Sedighian, H., \& Ghasemi, E. (2015). New Evidence of Paleolithic Activity from South Khorasan, Eastern Iran. Antiquity, 89.

Otte, M. (2015). Central Asia as a Core Area: Iran as an Origins for the European Aurignacian, International Journal of the Society of Iranian Archeologists, 1, 19-23.

Sadraei, A., \& Anani, B. (2018). Kalat-e Shour, Sarayan, Evidence of the Presence of Pleistocene Population in the Eastern Iranian Plateau. L'Anthropologie, 122, 722-736. https://doi.org/10.1016/j.anthro.2018.10.005

Sadraei, A., Mehne, M. F., Saburi, H., Garazhian, O., \& Azar, M. (2017). New Evidence of Middle Paleolithic Period in Sabzevar Plain, Northeast of Iran. Archaeology, 5, 1-6.

Sadraei, A., Mehne, M. F., Toghraei, M., Anani, B., \& Azar, M. (2018). The Probable Lower Paleolithic Evidence from Darongar River, Dargaz, North Khorasan, Iran. Archaeology, 6, 6-11.

Shea, J. J. (2013). Stone Tools in the Paleolithic and Neolithic Near East. Cambridge: Cambridge University Press. https://doi.org/10.1017/CBO9781139026314

Vahdati Nasab, H., \& Feyz, Z. (2004). Investigation and Identification of Paleolithic Sites in the Northern Margin of Iranian Central Desert, between Semnan and Sorkheh. In Proceedings of the 12th Annual Archaeological Forum (pp. 466-468).

Vahdati Nasab, H., \& Hashemi, M. (2016). Playas and Middle Paleolithic Settlement of the Iranian Central Desert: The Discovery of the Chah-e Jam Middle Paleolithic Site. Quaternary International, 408, 140-152. https://doi.org/10.1016/j.quaint.2015.11.117

Vahdati Nasab, H., \& Hashemi, M. (2018). Chah-e Jam, a Paleolithic Site in Southern Damghan. Iranian Journal of Archaeological Research, No. 16, 26.

Vahdati Nasab, H., Clark, G. A., \& Turkamandi, S. (2013). Late Pleistocene Dispersal Corridors across the Iranian Plateau: A Case Study from Mirak, a Middle Paleolithic Site on the Northern Edge of the Iranian Central Desert (Dasht-e Kavir). Quaternary International, 300, 267-281. https://doi.org/10.1016/j.quaint.2012.11.028

Vahdati Nasab, H., Roustaei, K., \& Rezvani, H. (2007). Delazian (Mirak 1). Evidence of the Paleolithic Settlement of the Northern Margin of the Iranian Central Desert, Semnan Province. Letter of the Research Institute, 20-21, 9-14.

Vahdati Nasab, H., Roustaei, K., \& Rezvani, H. (2010). Delazian (Mirak I): Evidence of Paleolithic Settlement at the Northern Edge of the Iranian Central Desert. In P. Matthiae, F. Pinnock, L. Nigro, \& N. Marchetti (Eds.), Proceedings of the 6th International Congress on the Archaeology of the Ancient Near East. Wiesbaden: Harrassowitz Verlag. 